\title{
Folkelig propaganda under treårskrigen
}

\author{
Af Jorgen Slettebo.
}

1 1800-tallels første halvdel blev stadig større kredse optaget af politik. Talrige provinsaviser blev grundlagt, adskillige pjecer, bøger og tidsskrifter så dagens lys, og i nystiftede læseforeninger gjorde man bekendtskab med alt det nye. De liberale bevægelser udover Europa satte sig spor også i Danmark, særlig juli-revolutionen i 1830, der bl. a. gav anledning til Uwe Jens Lornsens flyveskrift om Slesvig-Holstens forfatningsforhold. På samme tid trådte også de nationale problemer frem, og hurtigt henledtes opmærksomheden mere og mere på hertugdømmerne. Men det var ikke blot Sønderjylland, der vågnede. Da stænderforsamlingerne indførtes i 1834, blomstrede den politiske interesse overalt $i$ landet for alvor op. Valgene dertil gav anledning til politisk debat, og gennem Stændertidende blev en række politiske spørgsmål lagt frem som grundlag for en offentlig drøftelse. Foreløbig gav denne sig især udslag i talrige petitioner, hvor man henvendte sig til stænderforsamlingerne, men meget snart sivede diskussionen også ind $\mathbf{i}$ avisernes spalter. Det er karakteristisk, at det gamle, forhen så ansete, men akademisk prægede, regeringstro tidsskrift „Pro-

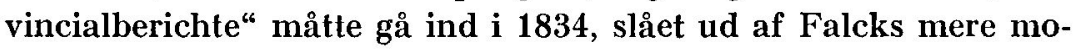
derne tidsskrift "Neues staatsbürgerliches Magazin" og det mere politisk prægede, liberale »Schleswigholsteinische Blätter «."

Mens aviserne for 1830 enten havde været direkte talerør for regeringen eller rene annonceorganer, begyndte de nu at af'spejle den nyvakte politiske interesse. I hovedstaden startede i 1834 det liberale „Fædrelandet“ med Orla Lehmann og Carl Ploug i ledelsen. Det blev sammen med „Dagen“, det konservative „Berlingske politiske- og Avertissementstidende" og det mere moderat liberale „Kjøbenhavnsposten“ fra 1827 landets mest udbredte blade med politisk indhold. Også i provinsen begyndte talrige aviser at beskæftige sig med politik, således „Fyns Stiftstidende“ under 
Søren Hempels ledelse og „Aalborg Stiftstidende“, der fra 1838 redigeredes af den liberale Bernhard Rée. Adskillige af de aldre provinsblade som det i 1794 grundlagte „Aarhuus Stifts AdresseContoirs Tidender" holdt sig dog sladig fra det politiske stof."

Hertugdømmerne var i ârene for 1848 godt dækket med aviser. Her var længe udkommet upolitiske sintelligensblade' af rent lokal karakter i de enkelte købstader. ${ }^{3}$ Fra 1838 udsendtes sá i Haderslev „Dannevirke“ med P'. Chr. Koch som redaktar, og i 18:39 fulgte Frederik Fischers „Apenrader Wochenblatt", der âret efter blev dansksproget. Slesvig-holstenerme benyllede sig iswer af $\gg$ Kirler Correspondenz-Blatt", der fral $18: 30$ blev udgivet af Theodor Olshausen og af „Itzehoer Wochenblatt“, men ogsä „L:kernförder Wochenblatt" og "Lyna" i Haderslev var slesvig-holstensk sindede. Det var i den første tid imidlertid ikke sâ meget det nationale, der skilte, som det liberale kontra det konservative. Da det i 1839 gjaldt on at standse Hans Kopperholts „Allgemeine Wochenblatt" i Åbenrâ, fordi han ubesindigt ytrede liberale anskuelser, var regeringerne i Kobbenhavn og pá Gottorp fuldtud enige. ${ }^{4}$

Antallet af blade øgedes sâledes, og samtidig blev deres indhold yderligere kendt gennem de voksende læseforeninger. I den nystartede læseforening i Odense holdt man 1837 de københavnske „Dagen“, „Fædrelandet“, og „Collegialtidende“, „Berlingske Tidende“ og „Kjøbenhavnsposten“ og fra hertugdommerne „Dannevirke“ og "Itzehoer Wochenblatt". Konservative og liberale, danske og slesvig-holstenske synspunkter var således lagt frem til medlemmernes overvejelse. ${ }^{5}$

Begge parter i den nationale strid var da også klare over aviserues betydning for den politiske meningsdannelse. Regeringen $i$ Kobenhavn holdt opmarksomt øje med bladenes indhold, og kongetro mænd benyttede af og til lejligheden at understrege deres synspunkter i de københavnske blade, hvorfra provinsbladene sâ bragte fyldige referater. Pâ den anden side var de slesvig-holstenske førere ivrige leverandører til en række aviser $i$ hertugdommerne. Ilertug Christian August holdt sig i nojeste kontakt med flere af disse aviser og foranledigede eller skrev ligefrem selv indlæg, især til „Itzehoer Wochenblatt“. Da regeringen i 1848 blev klar over den slesvig-holstenske bevægelses styrke, overvej- 


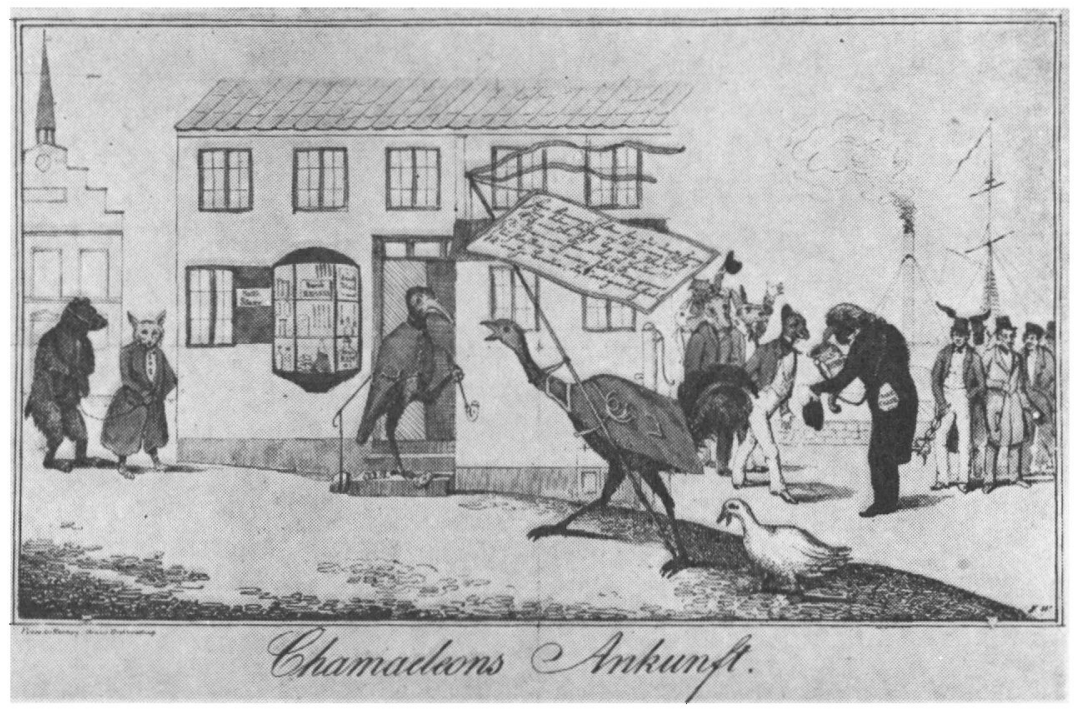

Fig. 1. Karikatur af P. Hiort Lorenzen.

$P$. Hiort Lorenzen som kamaleon modtages af sine tilhangere. (Mâske $i$ Sonderborg, hvor hun var valgt, se rådhuset). Koloreret stik, trykt i Hamborg. Mus. på Sbg. Slot.

ede den endda at købe „Itzehoer Wochenblatt“ for derigennem at øge sin indflydelse $\mathrm{i}$ Holsten og indskrænke modpartens agitationsmuligheder. ${ }^{6}$

Det stod dog klart, at den saglige, men som regel omslændelige og efter tidens skik særdeles tørre skriftlige fremstilling i pjecer, boger og aviser kun havde chancer overfor et meget beskedent mindretal. Den politiske salire havde imidlertid under Napoleonskrigene vist sig at vare et sardeles virksomt vâben, der isaer blev udnyttet i England og Frankrig. Herhjemme havde „Corsaren" fra 1840 sat ind med en fryglet skriftlig satire, - tegningrerne var der ikke meget bid i. Slesvig-holstenerne benyttede da ogsâ straks samme váben mod leter Hiort Lorenzen, da han i 1842 havde talt dansk i stændersalen i Slesvig. Snart efter udsendtes to store kolorerede stik, det ene med Hiort Lorenzen som en kamxleon, der skiftede farve efter omgivelserne (fig. 1), det andet med en kalkunsk hane, der modtager en deputation med tak-adresser og et bæger. ${ }^{?}$

Den propaganda, der valdede frem over landet, da oprøret 


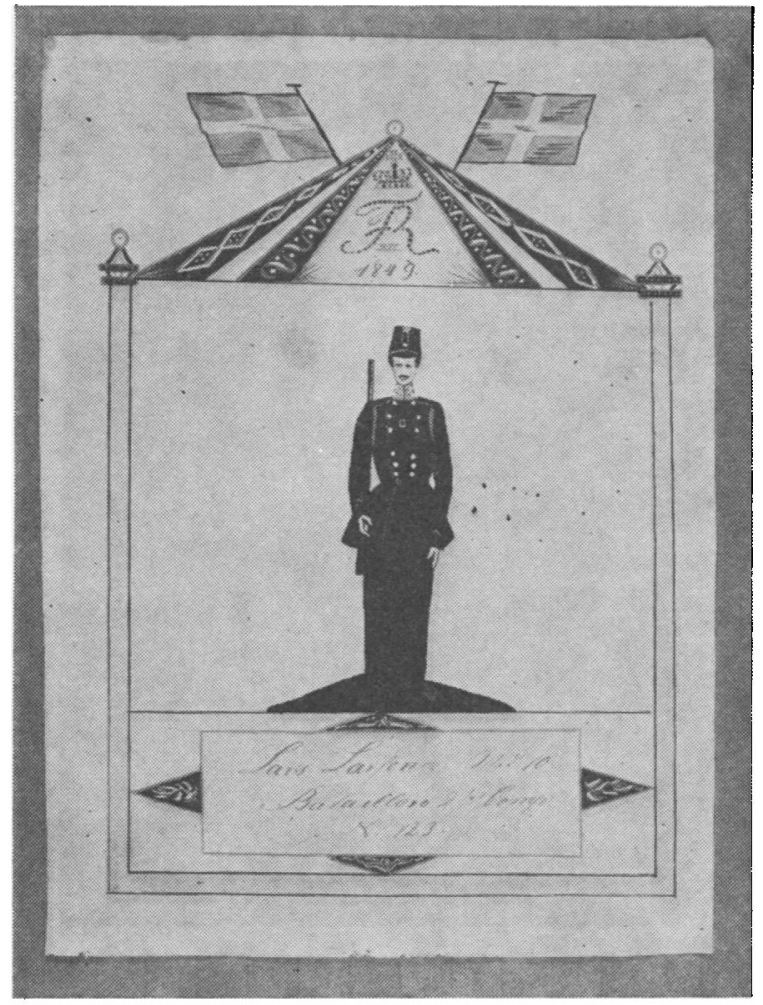

Fig. 2. Dansk soldat fra 1848.

Ligesom den menige soldat var helten $i$ de fleste viser, var der almindelig begejstring for soldaten, der deltog $i$ krigen. I mange hjem arede man ham ved at have et billede af ham hangende pá vaggen - her er det nr. 123 ved 10. Bataillons 2. Comp., Lars Larsen. Mus. på Sbg. Slot.

brød ud i marts 1848, byggede således på vel forberedt grund og skyldtes ikke blot den øjeblikkelige situation. En øget politisk interesse og en stadig storre medleven i statens og samfundets forhold havde udviklet sig i stigende tempo den sidste snes år. ${ }^{8}$

Straks ved oprørets begyndelse søgte man på alle måder at vinde befolkningen for sig og eventuelt smæde modstanderen. Der fremkom et utal af bekendtgørelser og opråb. Oprørsregeringen udsendte straks flere proklamationer, og gennem hele krigen udstedtes fra begge sider utallige offentlige henvendelser. Mange af- 
tryktes i aviserne, men de fleste udsendtes som etbladstryk i stort oplag til opslag eller fremlæggelse. Til en snævrere kreds henvendte sig de mere fyldige redegørelser for egne synspunkter, der også kom i stort tal. F. eks. udsendte geheimearkivar C. F. Wegener en stærk partisk redegørelse for hertug Christian Augusts opførsel i årene før krigen, „Om Hertugen af Augustenborgs Forhold til det holstenske Oprør", og konsistorium ved Københavns Universitet startede 1848 en samling historiske afhandlinger om Slesvigs tilhørsforhold til Danmark. Antislesvigholstenske Fragmenter".

Avisernes redaktører søgte at følge med i krigsbegivenhederne så godt som muligt, men det kneb at få oplysningerne hurtigt og korrekt frem. Selv vigtige begivenheder som slaget ved Bov 1848, ved Fredericia 1849 og ved Isted 1850 var mindst tre dage om at nå frem til de københavnske aviser. Under indtryk af folks iver efter at få krigsnyhederne hurtigt frem startede redaktør A. P. Liunge i 1849 „Avis Salonens Nyhedsblad“, der på to små oktavsider bragte de seneste nyheder fra fronten, ofte $i$ to daglige numre. Hurtigheden blev dog ikke meget større. Det første rygte om affæren i Eckernførde den 5, april 1849 nåede først frem om aftenen den 7. En officiel kundgorelse kom i bladet den 8 . kl. 9, nærmere enkeltheder blev så trykt i numrene den 8., 9., 10. og 11., og endelig den 13 . bragte man et stort udtog af den officielle beretning, som chefen for "Christian VIII", kommandørkaptajn Paludan havde sendt fra krigsfangenskabet i Rendsborg.

Korrekte var oplysningerne heller ikke altid. Den store opstandelse, der fulgte rygterne om, at oprørerne i Rendsborg havde frigivet slaverne fra tugthuset, og at de nu drog hærgende op gennem Jylland, er et klart vidnesbyrd om rygternes gode kår ${ }^{9}$. Og selv om Liunge i sit forste nummer lovede at undgå rygter og usikre oplysninger, så forledte ønsketænkning ham til gennem længere tid at publicere meddelelser om en stor russisk hjælpe-eskadres færd gennem de danske farvande. Den dukker op i spalterne første gang som et rygte om russisk støtte den 5. april, den 16 . juni var der 9 linieskibe og 4 fregatter undervejs, den 24 . gives der vejledning for befolkningen i Sønderborg om, hvordan den skal forholde sig — bl. a. for at undgå kolera — når den russiske eskadre nu ankommer, og den 29. rapporteres den udfor Møen. I 


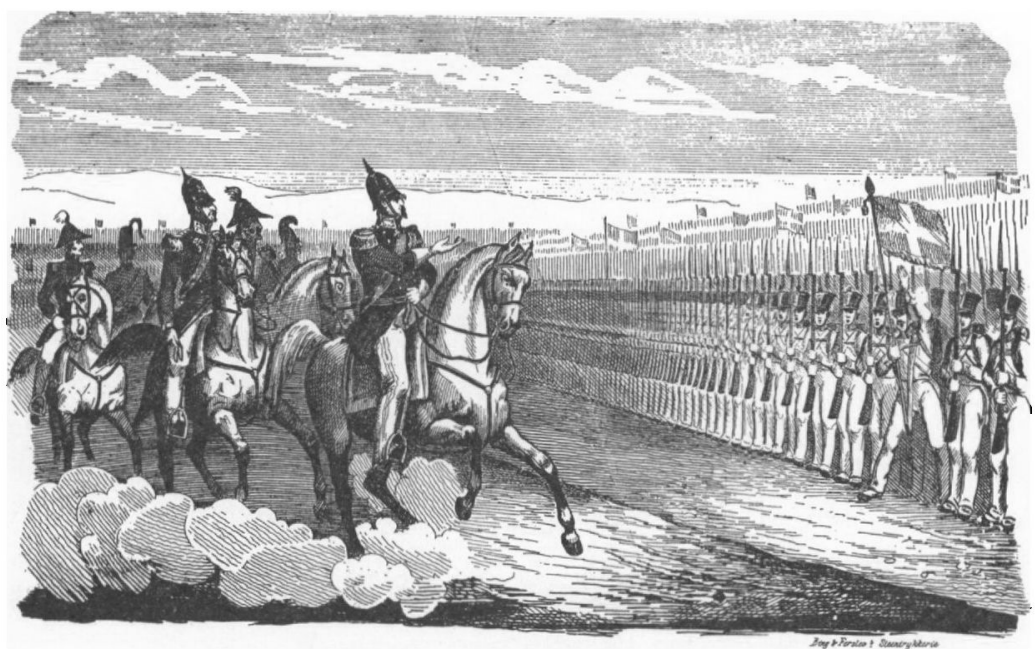

\section{fang fredetih ben suventes hevule over fjaren ved reile}

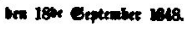

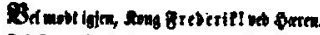

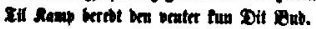
Bwor Slectunt blobigit var, vi frelife werem Eat of be trofitg fagtt Striber wi!

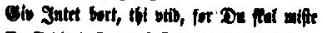
En Bobbrot Joch of Dine gatres Bant,

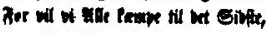

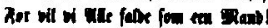

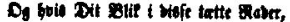

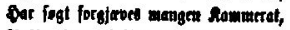

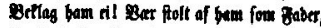
Og buf, for Dig gent bobe for Golbet. 3 Dobent Chutb og. pilt fine fin silere

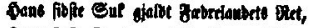

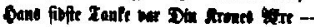

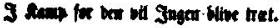

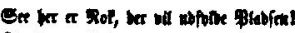

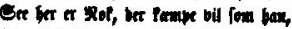

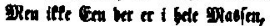

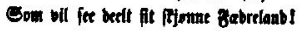

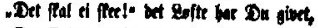

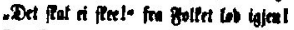 \\ Dge longen tio i Deven fon i givet,

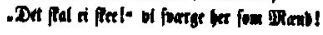

Fig. 3. Frederik VII afholder revy.

1848 afholdt Frederik VII revy over haren ved Vejle. Situationen blev gengivet $i$ et stik udgivet af Bing og Ferslev, hvor den populare vise "Vel modt igjen, Kong Frederik" også blev gengivet.

det hele taget gengives de fleste rygter til fordel for Danmark med stor trofasthed.

Krigens begivenheder gav ofte anledning til patriotiske vers, of te mere velmente end velskrevne, og de aftryktes tit på avisernes forsider. De bedste spredtes i håndskrevne visebøger, og bogtrykkerier overalt $\mathrm{i}$ landet udsendte de populæreste $\mathrm{i}$ talrige oplag. Størst yndest nåede nok „Dengang jeg drog afsted“, men også sange som "Vel mødt igen, Kong Frederik, ved Hæren « af H. P. Holst (fig. 3) og „Pâskeklokken kimed mildt", der blev sunget første gang i maj 1848 ved en koncert i Casino til fordel for de sårede og de faldnes efterladte i slaget ved Slesvig 23. april, blev sunget hyppigt. Langt de fleste sange er forlængst glemt, men ved 
et gennemsyn af bladenes iøvrigt meget sparsomme annoncesider får man et indtryk af, hvor mange der var tale om, idet boghandlerne fyldte en væsentlig del af annoncespalterne: I Berlingske Tidende den 5. jan. 1849 annoncerer både boghandler F. H. Eibe og boghandlerne Hermann og Erslev „bøger og sange fra krigen“, den 19. tilbyder Eibe „en samling feltdigte“, og den 1. febr. har boghandler J. Nielsen en "Mindekrans for Fædrelandet“ til salg. Den 12. marts har boghandler H. P. Møller en samling "KrigsSange“, og to dage senere tilbyder han „Hæren, Kongen, Gud En Digtning i 3 Afsnit«. Visedigteren Kobber-Jens på Skanderborgegnen fortalte endda: Da krigen brød ud i 1848, fik jeg især travlt med at digte og sælge viser, thi dengang var der liv i folk, og alle vilde have viser, og alle vilde synge ${ }^{10}{ }^{10}$ En håndskreven visebog fra Mindebjerg på Als, skrevet 1848 , indeholder fem viser, hvortil siden er føjet endnu en. De første viser er på 15, 26 og 23 vers, og kun de to sidste er på hver 7 vers, mens den tilføjede har 16 vers. ${ }^{11}$

Ikke blot skillingsviser og sange, men også skildringer af enkelte begivenheder gik i stort oplag. $\mathrm{H}$. J. Bing averterede i 1850 med "Episoder af Krigen i 1848 og 1849“ og F. H. Eibe bl. a. "Den danske Hærstyrke i 1848", „Danmarks Frelse " og - i en oversættelse fra tysk ved P. Chr. Koch - Hele Slesvig eller Krig! ${ }^{12}$ Hos J. Nielsen solgtes, En trofast Beretning om Stormen på Frederiksstad“ på i alt 16 sider med en "Takadresse til Hæren " som indledning og side 16 optaget af oplysninger om, hvad boghandler Nielsen i øvrigt havde på lager: Portrætter af Bülow, Rye, Hedemann, Krogh og de Meza, alle til 1 rbd. stykket, fuldstændige beretninger om slagene ved Fredericia og Isted til 8 og 10 sk., en skildring af det slesvig-holstenske oprør og en række sange, bl. a. „Til Danmarks Nutidshelte“ og "Sang for vore tapre Krigere. “13

Portrætter udsendtes der mange af, enten enkeltvis eller flere på et ark, af og til endog gruppebilleder, forsynet med en fint tegnet ramme: „Forsamling“ eller „Reunion“ hedder et med både dansk og fransk tekst, der viser general Krogh omgivet af hærens øverste officerer i $1850 .{ }^{14}$ Efter hvert vundet slag gjaldt det om at komme først med heltenes billeder. Allerede den 19. juli 1849 meddelte J. Nielsen, at han om få dage kunne levere et portræt 


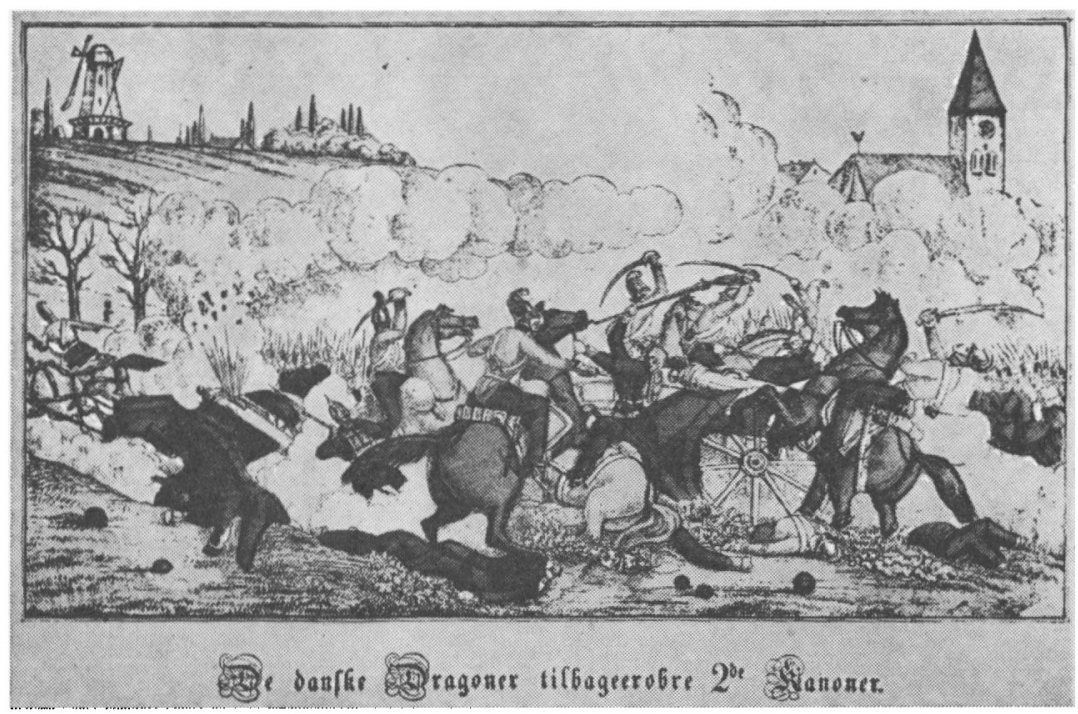

Fig. 4. Danske dragoner erobrer to kanoner.

En af de danske fremstillinger af en dansk krigsbedrift, hvor den danske Jens udmarker sig. $M$ us. på Sbg. Slot, i flere udgaver.

af Olaf Rye, udført $i$ det Bærentzenske Institut. Noget bagefter kom A. Levin i Aarhus, som d. 31. juli averterede, at malermester Søren Møller Jørgensen havde taget 5 daguerreotypier af Rye, og at tegneren Gertner nu lavede et portræt efter disse. Så snart det var færdigt hos litografen, kunne det købes hos Levin. ${ }^{15}$

Krigsscener var også efterspurgte. Allerede i september 1848 udsendtes fra C. M. Tegners Institut en serie på 6 blade efter tegninger af Niels Simonsen. Fra februar 1849 udsendtes efterhånden en serie fra A. Kittendorff, også efter forlæg fra Niels Simonsen, og umiddelbart efter krigens afslutning kom flere mindre serier. Den største og populæreste af billedserierne omfattede $i$ alt 24 blade, der kom tre og tre og fordeltes $i$ to hefter. De blev udgivet fra maj 1851, altså efter krigens afslutning, hos I. W. Tegner og A. D. Kittendorff efter forlæg af N. Simonsen og F. C. Lund. ${ }^{16}$

De fine litografiske portrætter og billeder var imidlertid ret dyre, og de lidt simplere skillingstryk blev nok spredt videre omkring (fig. 4). De holdt sig måske ikke så nøje til virkeligheden, 


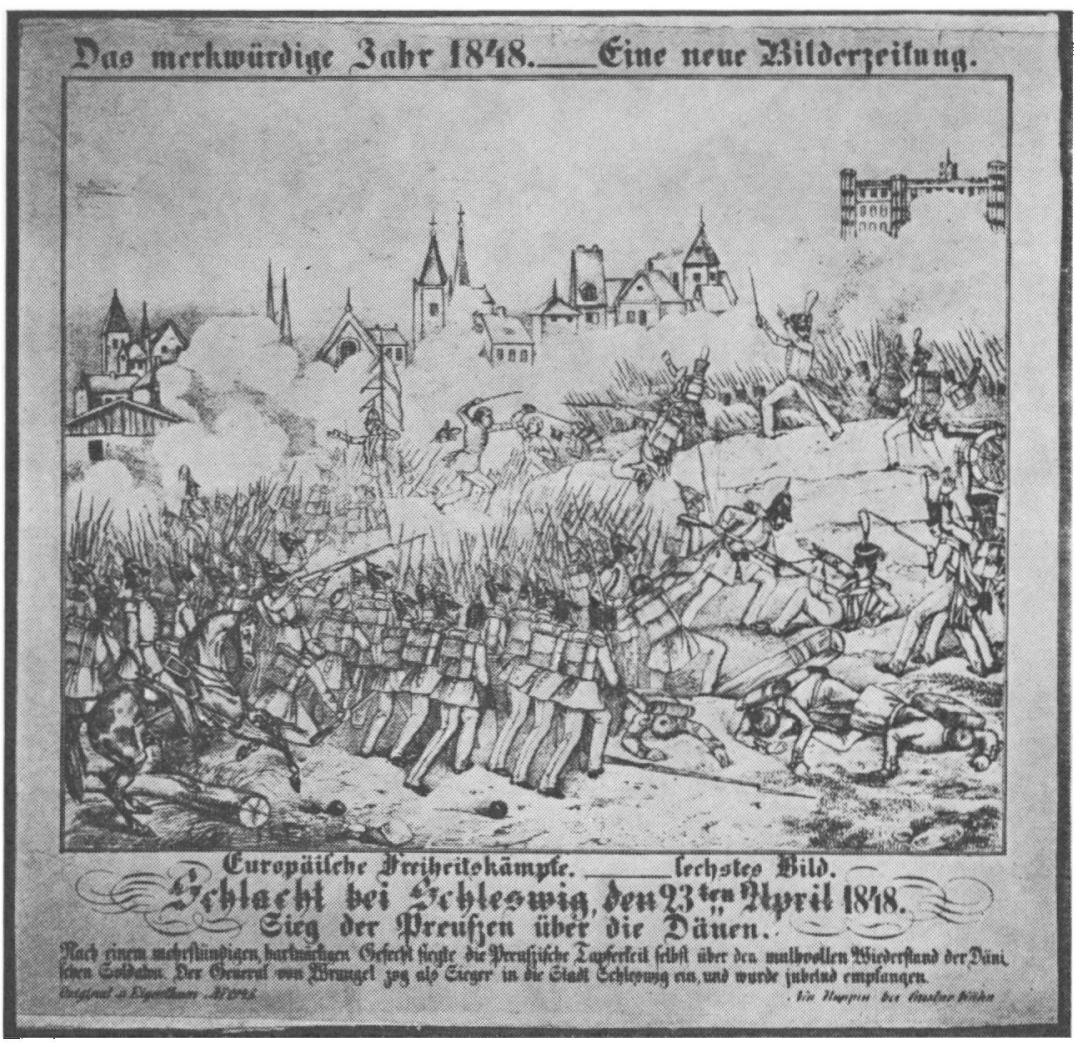

Fig. 5. Neu-Ruppin-ark.

Der var ikke stor forskel på de danske og de tyske enkeltbladstryk. Fra Neu-Ruppin kom bl. a. en serie med motiver fra tyske frihedskrige, trykt hos det produktive firma Oehmiche und Riemschneider. Mus. pả Sbg. Slot.

men talte des mere til fantasien. Firmaerne Chr. Steen og Søn, Bing og Ferslew og B. A. Meyer udsendte en del scener fra krigen, bl. a. »Danske Soldaters Afrejse fra Kjøbenhavn«, "Slaget ved Bov“, „De fynske Dragoner fordriver Slesvig-Holstenerne fra Jernstøberiet ved Flensborg“ (i tre forskellige udgaver), „De danske Dragoner i Slaget ved Slesvig“ og „Bivouak efter Slaget ved Slesvig“ for blot at nævne nogle fra det første krigsår. Desuden tryktes en del som følgeblade til bøger og tidsskrifter. I alt udkom over 200 forskellige litograferede etbladstryk med motiver fra krigen, de fleste endda i store oplag. ${ }^{17}$

Der tryktes også en del af de noget grovere træsnit, således et 


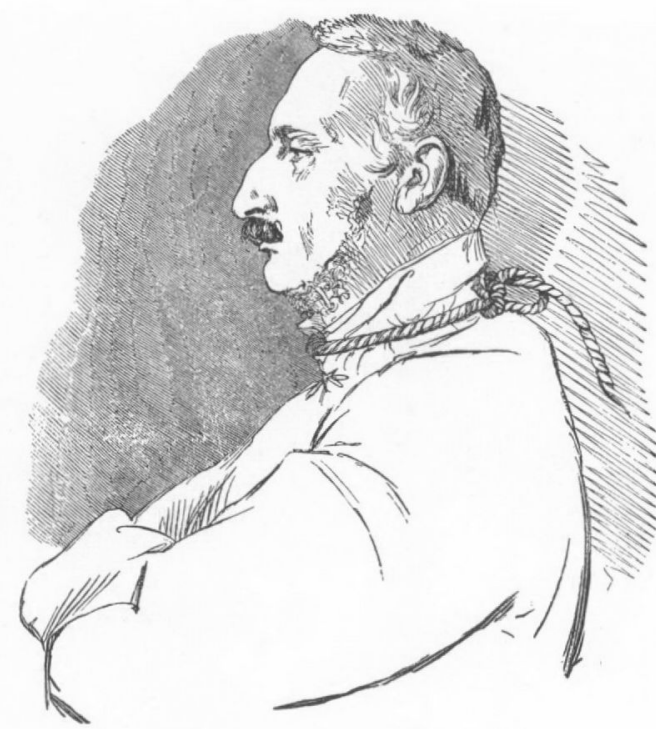

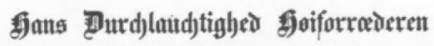

Prindien til 2fugutenborg (Noer).

Irafinittet of gling.

Inpth i vet Bertingfer Bogtrptteri.

Hibgibet af "Branbfutur".

Fig. 6. Prins Frederik af Nør med løkke om halsen.

Stik af C. V. Gertner. Mus. pá Sbg. Slot. Se ogsă fig. 8.

dobbeltportræt af den norske frivillige Leopold Løvenskjold og Olaf Rye, trykt hos Th. Petersen i Hjørring. På et blad fra samme trykkeri måtte politikeren Orla Lehmann dele pladsen med Bertel Thorvaldsen. Som træsnit findes også beskrivelsen af de to matroser Jensen og Schrøder, der undslap efter at være blevet fanget på et spejdertogt, et prospekt af slaget ved Fredericia og en fremstilling af Knippelsbro ved troppernes hjemkomst $1851 .^{18}$ I øvrigt var træsnittene, der havde oplevet deres blomstring med de talrige billeder af Struensees henrettelse, godt på vej til i 1830erne og 1840-erne at blive udkonkurrerede af billedarkene fra Neu-Ruppin. ${ }^{19}$ Og selvom antallet af danske etbladstryk fra krigen var stort, var tallet på Neu-Ruppin-ark dog større. Disses marked var da også meget større, da der dels solgtes billeder af 


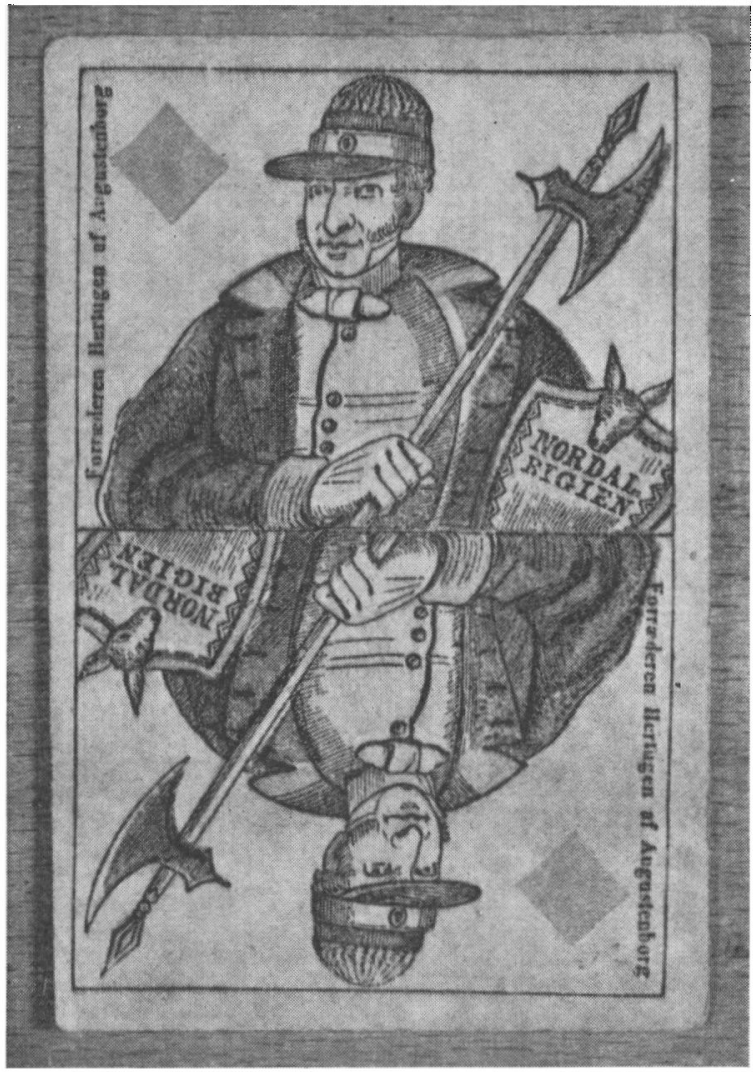

Fig. 7a. Hertug Christian August som knagt. Hertugen som ruder knagt på kortspil fra 1850. Mus. på Sbg. Slot.

slesvig-holstenske bedrifter og danske nederlag overalt $i$ hertugdømmerne og Tyskland, dels solgtes krigsbilleder med dansk tekst og danske sejre i Danmark. Her tog man ikke partihensyn. Lokalkendskabet var heller ikke stort. Et billede af kampene ved Dybbøl viser således Sønderborg som en drabelig fæstning med tre stærke forter - det ene slottet, der er blevet omgivet af kæmpevolde og svært armeret. ${ }^{20}$ En hel billedrække kom $i$ en serie om europæiske frihedskrige, og heller ikke her er den historiske nøjagtighed særlig stor (fig. 5).

Meget ofte solgtes krigsbøgerne og nogle af billederne til vel- 


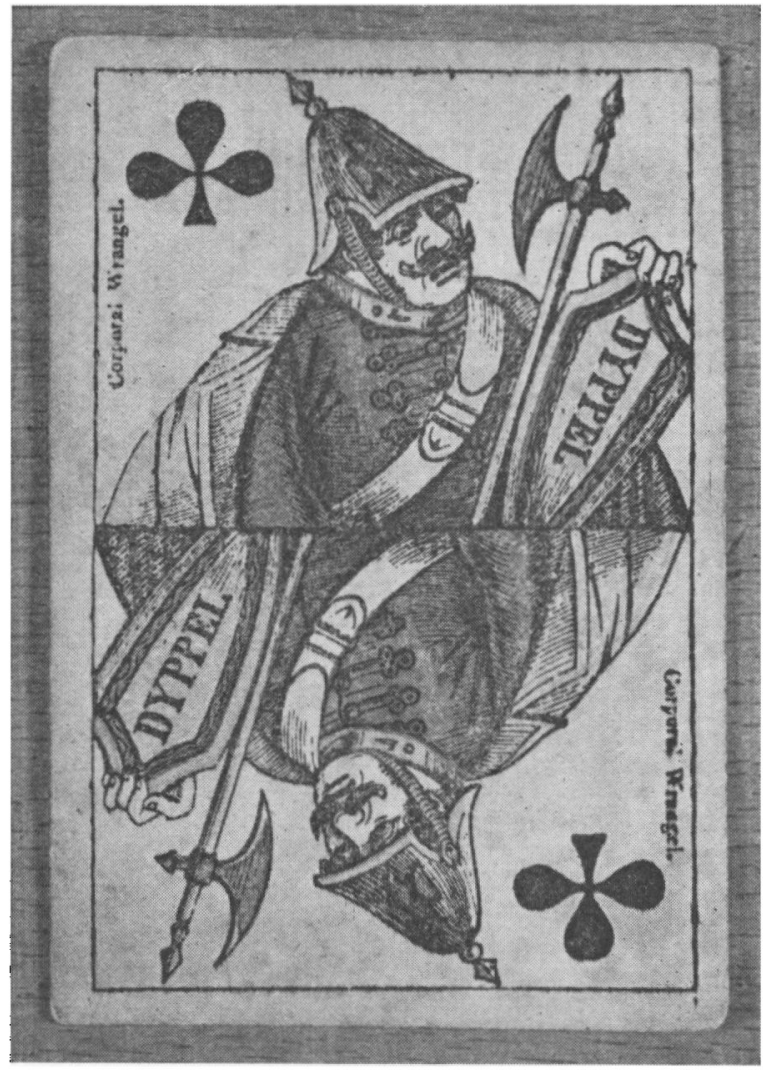

Fig. 7b. General Wrangel.

Generalen som klor knagt på kortspil fra 1850. Han tabte ved Dybbol 5. juni 1848. Mus. på Sbg. Slot.

gørende formål. Hos F. H. Eibe solgtes tolv prædikener af Fr. Hammerich til fordel for betrængte slesvigere, hos H. Chr. Bakke erhvervede man skriftet „Danmarks Frelse“, hvis netto-overskud gik til de sårede og de faldnes efterladte, hos boghandler C. W. Stinck solgtes en samling nye krigsviser til fordel for „de Skærtorsdag faldne Søkrigeres Efterladte", og sognepræst F. Schjødt, Askø, lod et af ham selv forfattet digt „Riffelen“ sælge hos boghandler N. A. Lund til fordel for „De i Krigen quæstede".21

For øvrigt var det ikke blot sådanne salgsindtægter, der tilfaldt de trængende. Der foranstaltedes adskillige indsamlinger til så- 


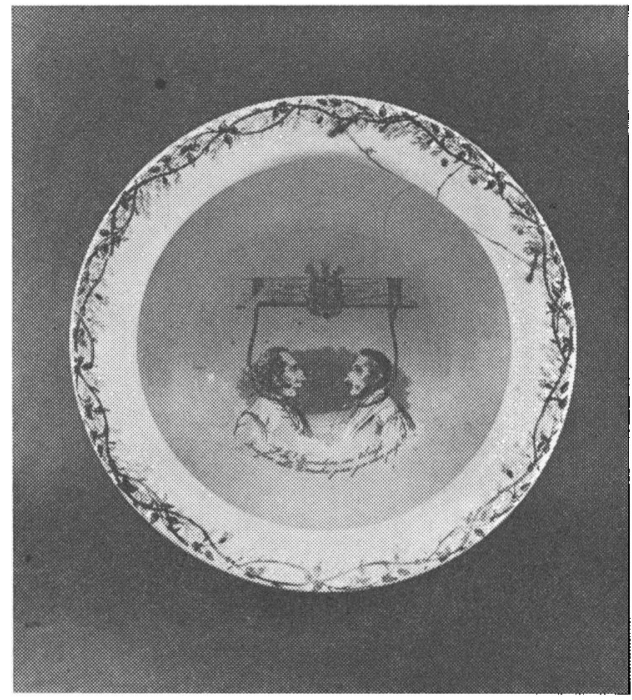

Fig. 8. Hertugen i natpotten.

Hvid fajance-natpotte med stikket af hertugen af Augustenborg og prinsen af Nor gengivet $i$ bunden over et smoedevers. Nationalmuseet, 3. afd.

rede, både af penge, tøj, linned og andet udstyr. „Dannevirke“ har den 4. nov. 1850 en annonce om uddeling af oksekød til krigsenker, og samme avis indeholdt flere gange tak til bidragydere til forskellige indsamlinger, ${ }^{22}$ ligesom soldater af og til indrykkede en tak, f. eks. til "beboerne i Lysabild sogn" eller til "Søsterhuset i Christiansfeld" ${ }^{23}$ Men også den gang gik det lettere, når man kunne forene det fornøjelige med det gode. Det kgl. Teater averterede da en forestilling, „En Søndag på Amager" til fordel for de betrængte jyder, og i august 1849 afholdtes til samme formål et "tre-Dages Marked i Rosenborg Have“ under kongens protektion. ${ }^{24}$ En basar på Herlufsholm modtog endda som kærkomne gaver „fra Hds. Maj. Enkedronning Caroline Amalie et Tæppe og fra H. K. H. Arveprinsesse Caroline en Trøster." 25

Udover at fremhæve egne fortjenester søgte man også at ramme modstanderen ved karikaturer og grovkornet satire. Det Berlingske Bogtrykkeri udsendte således et flyveblad med underskriften „Hans Durchlauchtighed Højforræderen Prindsen af Augustenborg (Noer) «, og i 1849 bragte Corsaren en karikatur af hertug 


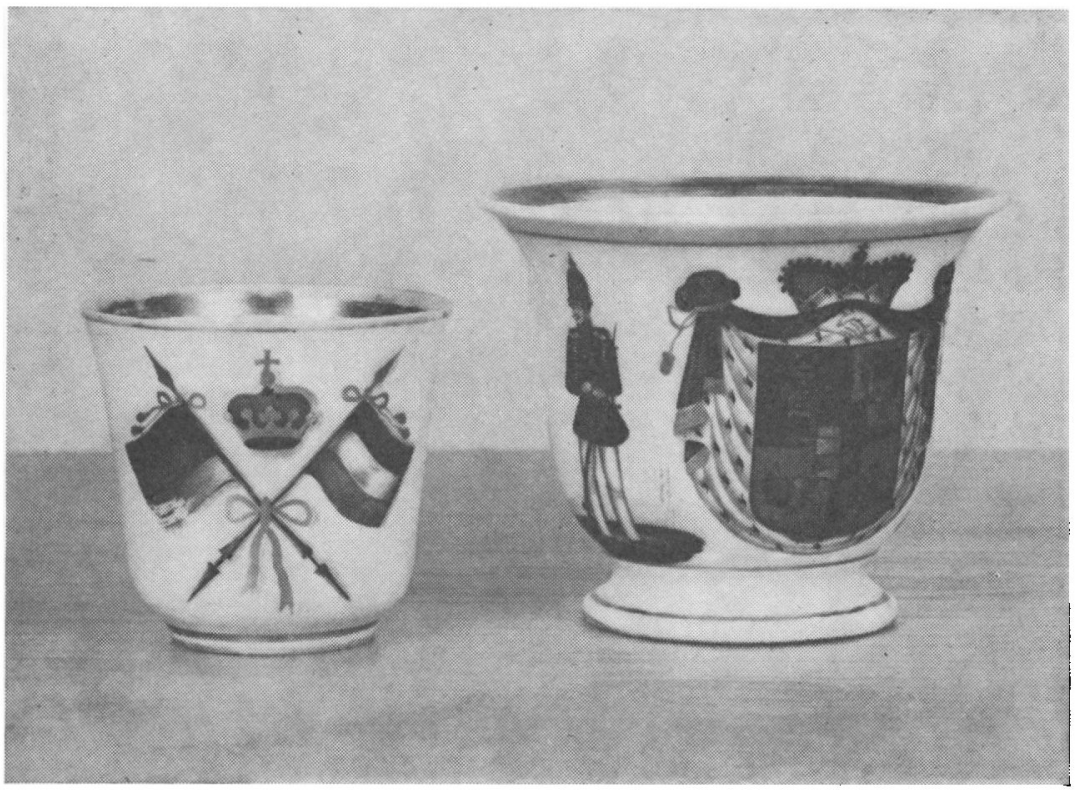

Fig. 9. To kopper.

T. v.: En kop med blå-rød-hvid fane t. h. og sort-rod-gylden fane t. v. - T. h.: Kop med vảbenskjold flankeret af to holstenske soldater. Mus. på Sbg. Slot.

Christian August. Vidt udbredt blev en række portrætter af hertugen og hans broder, begge med løkke om halsen, parat til hængning. Det findes i flere udgaver, bl. a. det her gengivne (fig. 6), og et, hvori begge står i hel figur bagbundne under galgen.

Et mere særpræget, men nok ikke så udbredt politisk-satirisk tryk fra 1850 var et kortspil, hvor de fire knægte blev erstattede af karikaturer (fig. 7a og b). Ruder knægt var hertugen af Augustenborg, hjerter knægt prinsen af Nør, og de to sidste knægte viste oprørshærens generaler Bonin og Wrangel. Begge har på deres våbenskjolde fået anbragt navnet på deres største nederlag, henholdsvis Fredericia og Dybbøl. Kortene er trykt hos kortspilfirmaet Bording og Ostermann, en afdeling af F. E. Bordings trykkeri. Kortene er trykt efter januar 1850, da kortspiltrykkeriet oprettedes, og er således nok et af de første spil, Bording og Ostermann fik udført. Da hverken slaget ved Isted eller oprørshærens general fra 1850, Willisen, nævnes, er det sandsynligvis trykt før 


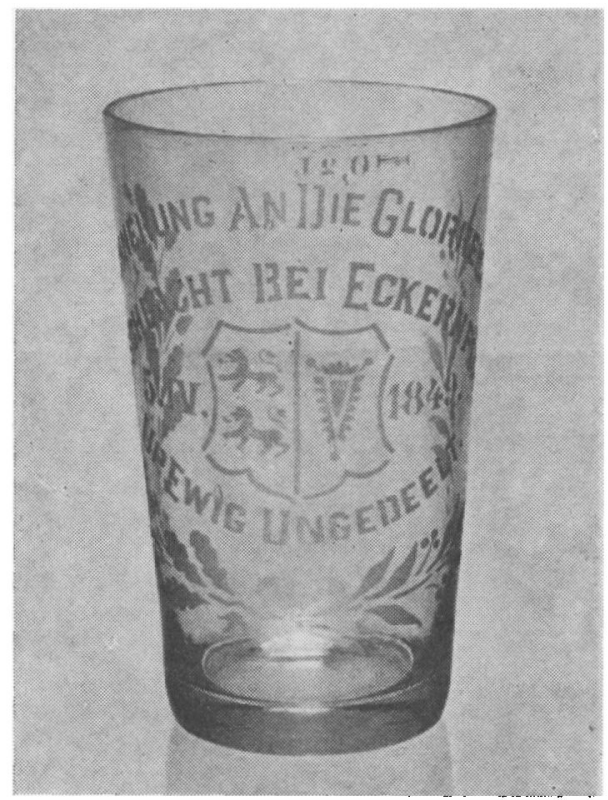

Fig. 10.

Glas med inskription.

Slesvig-holstensk mindeindskrift om sejren

ved Eckernforde

graveret på glas.

Mus. på Sbg. Slot.

juli 1850, da krigen igen brød ud. Fra F. E. Bordings trykkeri udsendtes i øvrigt adskillige populære sange, skillingsviser og politiske småskrifter under krigen. ${ }^{27}$

Endnu mere karikerende er tre blade, der blev trykt i Berlingskes Bogtrykkeri med træsnit af Flinch: „Allernyeste Efterretninger fra Krigsskuepladsen i Schleswigholstein, fortalte af Herr von Münchhausen i Hamburg". Hvert blad har 2-3 mindre billeder, bl. a. et af tre slesvig-holstenere, hvoraf den ene fanger granater med hænderne, mens den anden bruger sin sabel dertil, og den tredie bærer en hel flok danske soldater spiddet på sin bajonet. På et andet blad viser et billede en flok slesvig-holstenere, der slynger våben og tøj, endog bukserne, efter danskerne. Teksten, der fylder det meste af bladet, er på dårligt dansk isprængt tyske ord for at gore nar af neuruppinernes of te ubehjæelpsomme dansk. ${ }^{28}$

Den kendteste anvendelse af karikaturerne af hertugen og prinsen af Nør er vel imidlertid ikke de trykte blade, men nok billedet af dem som forrædere, anbragt $i$ bunden af en natpotte (fig. 8). Grundlaget er det omtalte flyveblad med brødrene parate 


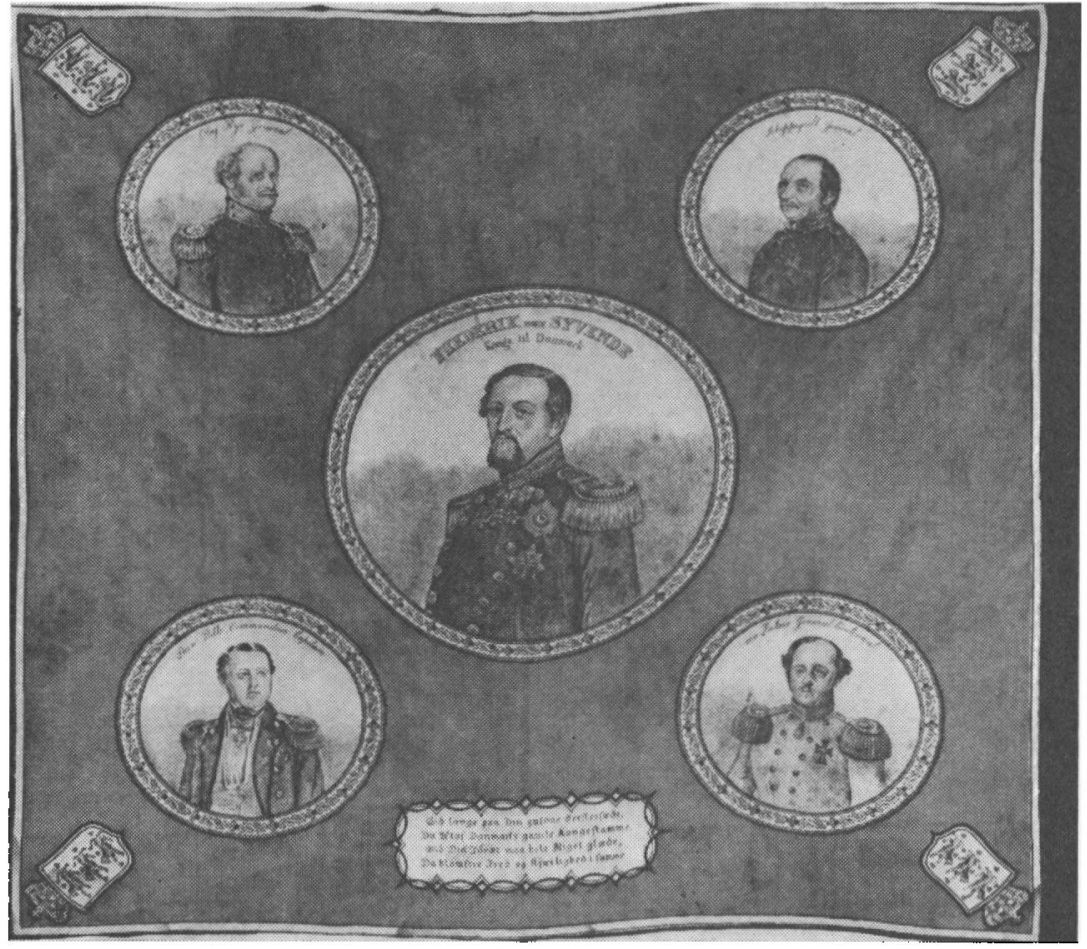

Fig. 11. Torklade med 5 portratter.

Tyndt bomuldstorkloede med 5 portratter $i$ kranse på rød bund. Portratterne er efter samtidige stik. Mus. på Sbg. Slot.

til at blive hængt, jvf. fig. 6. Natpotterne er mâske fremstillede i England, hvad teknikken tyder på. I så fald er flyvebladet først blevet sendt til England og de færdige potter returneret til salg i Danmark. Forhandleren var muligvis kgl. hof-porcellainshandler N. Petersen, Kgs. Nytorv, men i øvrigt ved man intet nærmere om handelen med dem. ${ }^{29}$

Natpotten er imidlertid ikke det eneste eksempel på, at porcelæn og fajance var velegnet til patriotiske illustrationer. Særlig udbredte blev pibehoveder i porcelæn med billeder af kongen eller med den danske landsoldat på. Disse 8-9 cm høje pibehoveder afgav fortrinlig plads til et aflangt billede, f. eks. en stående person. En slesvig-holstensk pibe viser en kronet dobbelteg, hvor to våbenskjolde er lænet op ad stammerne: det ene med Holstens 


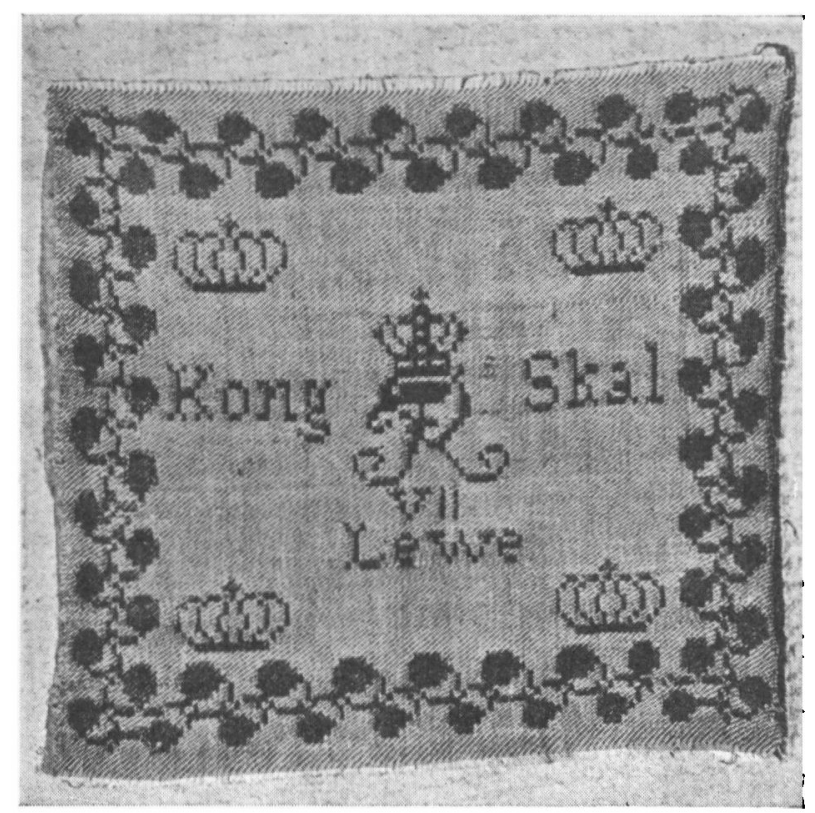

Fig. 12. Blät-hvidt torklade fra 1850.

Vovet af Chr. P. Lassen $i$ blatt-hvidt (de ovrige kendte er alle $i$ rodt-hvidt). Museet for Koldinghus Len, nr. 9730.

nældeblad, det andet med Slesvigs to løver. Piben er desuden forsynet med et vers: ${ }^{30}$

Theures Land, du Doppel-Eiche

Unter einer Krone-Dach.

Stehe fest, und nimmer weiche

Wie der Feind auch dräüen mag.

Også drikkekopper blev benyttede, f. eks. til afbildning af Frederik VII. En bred, $9 \mathrm{~cm}$ høj kop viser hertugdømmernes våben, flankeret af to af oprørshærens soldater: til venstre en holstensk infanterist og til højre en holstensk jæger (fig. 9 t. h.). En noget mindre kop har to korslagte faner, $t$. $v$. de tyske sort-rød-gyldne farver, t.h. slesvig-holstenernes blå-rød-hvide (fig. 9 t.v.). I det hele taget spillede de nationale farver en meget stor rolle, og kokarder både $i$ de danske og de slesvig-holstenske farver blev båret overalt."

Glas kunne selvfølgelig også bruges, men var åbenbart ikke så 


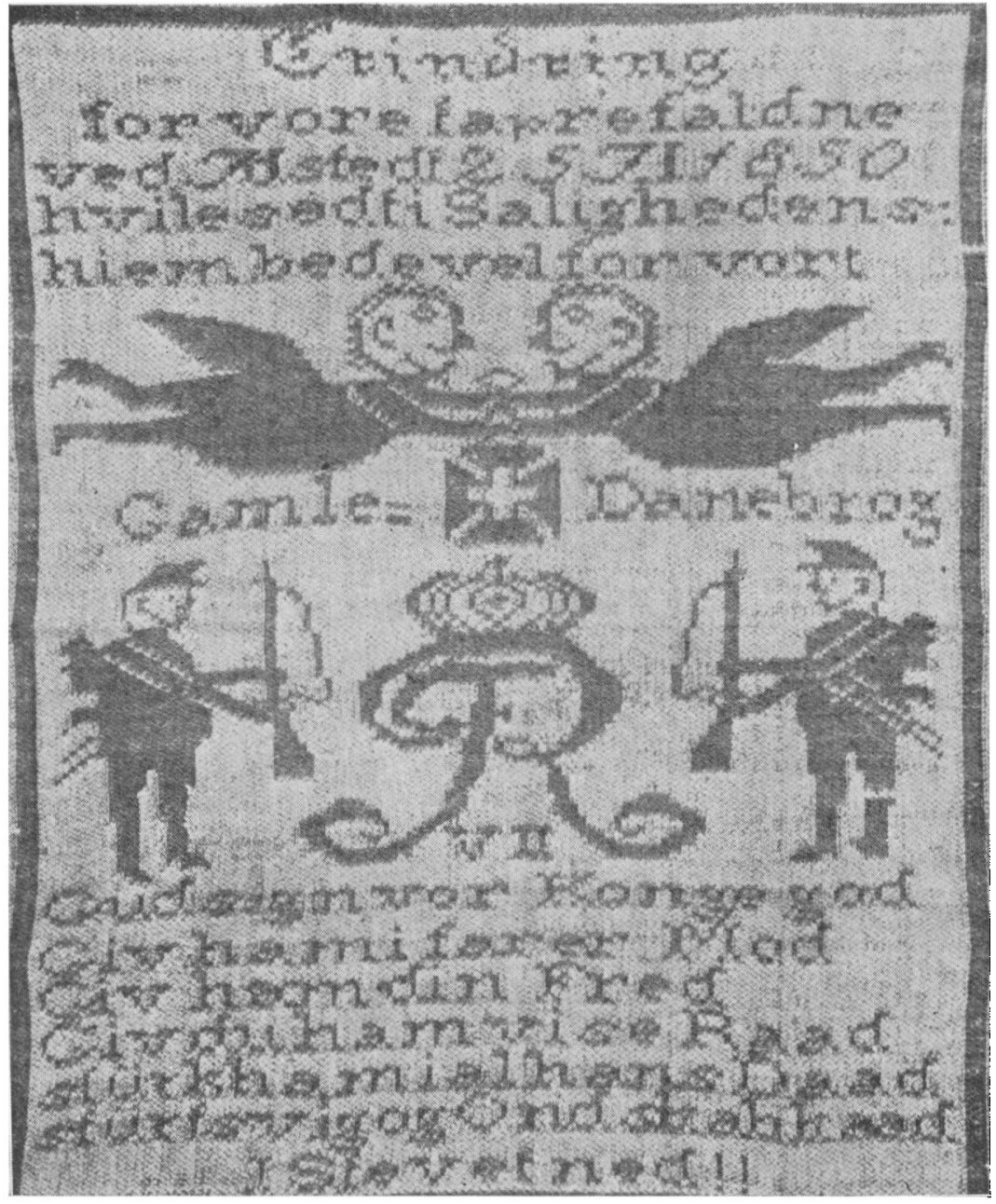

Fig. 13. Rodt-hridt torklade fra 1850.

Vavet af Chr. P. Lassen til minde om slaget ved Isted. Mus. på Sbg. Slot, V, 1675.

hyppigt udnyttet. Der findes dog et enkelt drikkeglas med indskriften: $₫$ Erinnerung An Die Glorreiche Seeschlacht Bei Eckernförde, 5. IV. 1849. Up Ewig Ungedeelt. * (Fig. 10). Måske er det dog noget yngre, f. eks. udført i forbindelse med en mindefest. ${ }^{32}$

De mest yndede litografier lod sig også gengive på tynde vævede stoffer, og der findes adskillige tørklæder med et portræt uf 


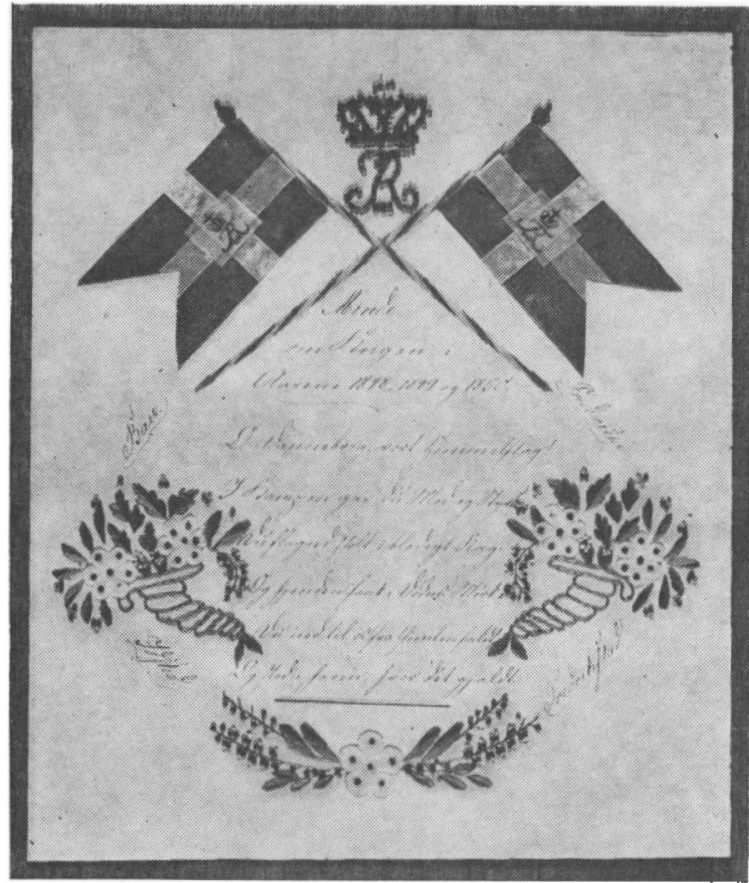

Fig. 14. Broderet og malet vagbillede.

Papirbillede med påsyede flag og silkebroderede buketter om haindskrevet vers. Kronen er broderet med glasperler og blomsterne er af udklippet stof. Mus. på Sbg. Slot.

Frederik VII direkte efter et af tidens stik. Også krigens helte måtte holde for, ikke mindst generalerne Rye, Schleppegrell og Krogh samt oberstløjtnant Helgesen. De kunne gengives enkeltvis eller i grupper som her, hvor Rye, Schleppegrell, Bülow og Sten Bille omkranser Frederik VII (fig. 11). ${ }^{33}$

De trykte tørklæder fremstilledes $i$ ikke ringe antal og solgtes til et forholdsvis sikkert marked. Men ligesom de finere litografier udsendtes side om side med de jævne skillingstryk, så fremkom også simple nationale vævninger ved siden af de lette torklæder.

Til de lidt grovere frembringelser hører en gruppe damaskvævede tørklæder i rødt og hvidt. ${ }^{34}$ De bærer som regel Frederik VII's navnetæk i midten (fig. 12) og har desuden gerne patriotiske symboler eller korte vers. Symbolerne var flag, landsoldater 
(fig. 13) eller ligefrem en stiliseret „oprorsslange“ — den sidsle forsynet med verset:

Gud har velsignet vores Bon og Oprorsslangen fik sin Lon 1850.

De blev fremstillet i ret stort tal, skont de alle fremstilledes af een vaver (der kendes nu omkring 20 , delt i 5 forskellige typer). Vaveren var den da ca. 30-ârige Christian Peter Lassen i Broager. Han blev siden ogsà fiskernger, da det kneb med at leve af væveriet, og han levede helt til 1897. På flere af torklæderne indvævede han navnet på køberen, så der har i nogle tilfælde været tale om forudbestilling. En del er muligvis blevet solgt på ture, han foretog med sit om vinteren oparbejdede lager. Kunderne var for en del soldater, der onskede sig et minde om krigen.

Der var i 1848 plads til bade den fineste og den primitivesle leknik, til det rent kunstneriske og det mere amatoragtige. „Aan-

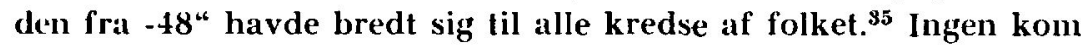
upavirkede gennem de tre krigsâr, men den store fælles begejstringsbolge ebbede dog noget ud inden 1850. Da krigen så først var lykkeligt overstâet, samlede man minder eller lavede dem selv, thi krigens resultat gav pany anledning til national stolthed og patriotisk loftelse, for mange dog parret med vemod over de faldne. I 1850 foranstaltedes store velkomstfester for den hjemvendende Jens, der nu atter mátte tilbage til sin civile tilværelse. ${ }^{36}$ Men rundt i hjemmene hang minderne, selvom de mâske indskrænkede sig til et lille selvlavet billede, bygget op om det rød-hvide flag og kampârenes sejrsnavne (fig. 2 og 14) ${ }^{37}$ Først $i 1864$ vågnede man atter op til den barske virkelighed.

\section{NOTER}

1. J. Brock: Den slesvigske rejsnings forhistorie, 1927, s. 72 .

2. C. Kirchhoff-Larsen: Den danske Presses Historie, I, 1943. N. Thomsen: Dagliglivet og Samfundet, s. 647-657. (I)agligliv i 1)anmark, I, 1963, s. 633-661).

3. Sv. Larsen: Pressen i Aabenraa ved Nationalitetskampens begyndelse, s. 104. (Festsk. t. H. P. Hanssen, 1932, s. 103-124). Juf. G. Japsen: Den nationale udvikling i Åbenra $1800-1850,1961 \mathrm{~s}$. 81 ; ff. R. Huhle: Aviser på Als i Bogen om Als, 1956, s. 386 ff. H. Hjelholt i Tonder gennem Tiderne, I, 1943, s. 216 ff. Bladet Dannevirke 1838-1938, s. $23 \mathrm{f}$. 
4. Sv. Larsen, a. a., s. 124 .

5. W. Norvin: Fyns Stifts Læeforening, 1908, s. $9 \mathrm{f}$.

6. A. F. Kriegers Dagboger, I, 1920, s. 36.

7. Mus. pả Sbg. Slot, nr. V, 1390 og 1391. Corsaren, nr. 123, 27. jan. 1843 omtaler det ene af disse blade, hvorved man har sikkerhed for, at de er udkommet i direkte forbindelse med de karikerede begivenheder.

8. P. Munch: Det danske Folks nationale og politiske Gennembrud efter Julirevolutionen, 1904, især s. 83-96. Jvf. H. Jensen i Schultz Danmarks Historie, IV, 1942, afsnit III, s. 423-527.

9. Lanborg Friis: Den jydske Slavekrig. 1898.

10. J. Piø: Folkedigtning, s. 167, i Dagligliv i Danmark, I, 1963, s. $139-170$.

11. Mus. på Sbg. Slot, nr. V, 70.

12. Berlingske Tidende, 7. jan. 1850 og 7. og 21. febr. 1849.

13. Mus. på Sbg. Slot, nr. V, 21.

14. Mus. på Sbg. Slot, nr. V, 144. Tegnet af S. Schack, trykt hos E. Bærentzen og Co.

15. Fædrelandet, 1849, 19., 25. og 31, juli.

16. J. Paulsen: Billeder fra Treîrskrigen. 1952, s. 216-220.

17. J. Paulsen, a. a., suppl., s. 221-234.

18. V. E. Clausen: Det folkelige danske træsnit i etbladstryk 1650-1870, 1961, nr. 289, 310, 432 og 434. Jvf. J. Paulsen, a. a., fortegn, nr. 10-14 og suppl. nr. 187 og 218.

19. V. E. Clausen, a. a., s. $51 \mathrm{f}$.

20. Mus. på Sbg. Slot, V, 392, jvf. 408 og 471.

21. Berl. Tid. 1849, 22. febr., 14., 16. og 23 april.

22. Dannevirke, 1850,4 . sept., 9., 22. og 31. okt. Jvf. Fædrelandet 1849, 30. april, 29. juni, 6 . juli og 1850,24 . aug.

23. Dannevirke 1850,10 . og 12. dec.

24. Fædrelandet 1849,6 . og 31. juli.

25. Avis-Salonens Nyhedsblad, 21. juni 1849.

26. H. Rasmussen: Danske Museer, II, 1951, s. 54 ff. En "politisk " Natpotte. Jvf. Mus. på Sbg. Slot, V, 154, 489 og 1154.

27. J. Slettebo: Nogle politiske kortspil. Arv og Eje, 1963, s. 55-72.

28. V. E. Clausen, a. a., s. 198 f., nr. 429-431.

29. Holger Rasmussen, a. a., s. 53-58.

30. Mus. på Sbg. Slot, V, 1615.

31. Mus. på Sbg. Slot, V, 1677 og 1688.

32. Mus. på Sbg. Slot, V, 1678.

33. Mus. på Sbg. Slot, V, 1490.

34. J. Slettebo: Nogle tørklæder fra Trearskrigen, Arv og Eje, 1958, s. 98-109.

35. C. E. F. Reinhardt: Det danske Folks nationale Opvækkelse i Aaret 1848. Folkelige Foredrag, 1868, s. 103-134. Jvf. N. Thomsen, note 2 a. a., s. $651 \mathrm{ff}$.

36. J. Paulsen, a. a., fortegn. nr. 417-426 og suppl. 186-188 er alle billeder fra troppernes hjemkomst og fester $i$ den anledning.

37. Mus. på Sbg. Slot, V, 904, 1502 jvf. 99.1403 og VII, 5967 m. primitive portrætter af den hjemvendte soldat. 